\title{
Influence of Limestone and Gypsum Application on Chemical Attributes of Dystrophic Yellow Latosol Soil and Corn Yield in Eastern Amazon
}

\author{
Sidney Daniel Araújo da Costa \\ Institute of Agrarian Sciences, Federal Rural University of Amazon, CEP.066.077 830.Belém, \\ Pará, Brazil. E-mail: sdanielcosta@ hotmail.com
}

Edilson Carvalho Brasil

Brazilian Agricultural Research Corporation (EMBRAPA), CEP. 66095-100. Belém, Pará, Brazil. E-mail: edilson.brasil@embrapa.br

\section{Mário Lopes da Silva Júnior}

Institute of Agrarian Sciences, Federal Rural University of Amazon, CEP.066.077 830.Belém, Pará, Brazil. E-mail: mario.silva_junior@yahoo.com.br

Received: Dec. 2, 2019

doi:10.5296/jas.v8i3.16744
Accepted: Mar. 10, 2020 Published: Mar. 24, 2020

URL: https://doi.org/10.5296/jas.v8i3.16744

\begin{abstract}
The objective of this study was to evaluate changes in the chemical attributes of the soil caused by the use of limestone associated or not to with gypsum in no-tillage system. The experiment was conducted on a dystrophic Yellow Latosol in Pará state, Brazil. The experimental design was in randomized blocks in split plots with three replications. The treatments consisted of five doses of limestone $\left(0,1,2,3\right.$ and $\left.4 \mathrm{t} \mathrm{ha}^{-1}\right)$, with and without gypsum $\left(0,0.5\right.$ and $\left.1 \mathrm{t} \mathrm{ha}^{-1}\right)$. Soil samples were collected at depths of 0-20 and 20-40 cm. There was a significant effect on the analyzed variables at both depths. The doses of 3.64 and $2.19 \mathrm{t} \mathrm{ha}^{-1}$ of limestone associated with $0.5 \mathrm{t} \mathrm{ha}^{-1}$ of gypsum, were responsible for the largest increase in soil calcium content in the 0-20 and 20-40 cm layers, respectively. The highest increase in $\mathrm{Ca}+\mathrm{Mg}$ content was found at $3.63 \mathrm{t} \mathrm{ha}^{-1}$ limestone combined with $0.5 \mathrm{t} \mathrm{ha}^{-1}$ gypsum. It was observed that $3.13 \mathrm{t} \mathrm{ha}^{-1}$ of limestone combined with $0.5 \mathrm{t}$ of gypsum increased soil CEC. The $2.89 \mathrm{t} \mathrm{ha}^{-1}$ dose of limestone combined with $0.5 \mathrm{t}$ of gypsum contributed to the increase in base saturation (V\%). The use of limestone and gypsum
\end{abstract}


promotes soil chemical conditions, as reflected by increased corn yield when compared with control (no treatment) plots.

Keywords: chemical attributes, no-tillage system, corn yield

\section{Introduction}

The intensive use of the conventional tillage system increases soil compaction and surface erosion and reduces water infiltration input of plant residues, all of which are caused by repeated plowing and harrowing practices (Fontana et al., 2016).

The use of conservationist systems such as no-tillage system (NTS) has been adopted in agriculture as an alternative means of reducing impacts caused by conventional systems on soil quality. The NTS has made it possible to increase or reduce the amount of organic matter, depending on the production and continuous permanence of vegetable residues besides promoting improvements in nutrient cycling (Valadão et al., 2015), erosion control, moisture conservation, amount of organic matter $(\mathrm{OM})$, increased biological activity and improved aggregate stability (Carvalho et al., 2010).

Despite the benefits, NTS faces some obstacles related to the management of soil chemical attributes, especially the process of soil acidity correction, since limestone application is superficial and without incorporation (Rheinheimer et al., 2018). The non-revolving soil causes the liming benefits combined with the superficial application of limestone, to be restricted to the first centimeters of the soil profile (Crusciol et al., 2016), with the formation of an alkalizing gradient, which decreases with the depth.

Given the limitation of limestone and in an attempt to broaden the improvements in the chemical attributes in the soil layers under NTS, means have been sought to act as a complement to the chemical changes provided by liming. As the solubility of gypsum $\left(\mathrm{Ca}\left(\mathrm{SO}_{4}\right) 2 \mathrm{H}_{2} \mathrm{O}\right)$ is greater than of $\mathrm{CaCO}_{3}$, it is responsible for the transport of exchangeable bases to the subsurface layers, therefore reducing aluminum activity and contributing to root growth over the profile (Zambrosi; Alleoni; Caires, 2007).

Rainfall may directly contribute to the limestone dissociation process, favoring more rapidly to the increase of soil $\mathrm{pH}$, thus allowing the percolation of anions from the dissociation of (gypsum ??) plaster bound to basic cations towards subsurface. According to Myiazawa et al., (2002) the water regime has great influence on the speed of action of these conditioners. Thus, regions with high levels of rainfall, such as the Amazon, can strongly affect the interaction of limestone and plaster, influencing the dynamics of solubilization products of these inputs in the soil and may affect crop yield under no-tillage system, especially in soils with low clay content, which have higher leaching rates, when compared to soils with greater water retention capacity. This condition can favor the movement of exchangeable bases to deeper layers, out of reach of the roots. Considering the lack of studies in Amazonic biome soils under no-tillage system that received application of limestone and gypsum, the present study complements the information existing in other tropical regions.".

The objective of this study was to evaluate the effects of the combined application of 
limestone and agricultural gypsum on the chemical attributes of a medium-textured dystrophic Yellow Latosol and its influence on the production of corn under no-tillage system in the Amazon.

\section{Materials and Methods}

The study was conducted over three agricultural cycles (2010/2011, 2011/2012 and 2012/2013) in the Experimental Station of Embrapa Eastern Amazon, located in Terra Alta, Pará state, Brazil, under the coordinates $01^{\circ} 02^{\prime} 28^{\prime \prime S}$ and $47^{\circ} 54^{\prime} 27^{\prime \prime} \mathrm{W}$. The experiment was set in a dystrophic Yellow Latosol soil with physical and chemical attributes shown in Table 1, at 0-20 cm and 20-40 cm depths.

A randomized complete block design was used in a split-plot scheme with three replications. The plots consisted of limestone doses $\left(0,1,2,3\right.$ and $\left.4 \mathrm{t} \mathrm{ha}^{-1}\right)$ and the subplots were gypsum doses $\left(0,0.5\right.$ and $\left.1 \mathrm{t} \mathrm{ha}^{-1}\right)$. A dolomitic limestone $(32 \% \mathrm{CaO}, 15 \% \mathrm{MgO}$ and $92 \%$ relative power of total neutralization) and commercial agricultural gypsum (25\% $\mathrm{CaO}$ and $14 \% \mathrm{~S}$ ) were used. Limestone and gypsum was surface-applied and incorporated by plowing and harrowing only at the beginning of the first agricultural cycle and none thereafter, according to the combination of treatments.

In all agricultural cycles, corn (Zea mays L.) was used and sowed in experimental units composed of eight rows of eight meters in length, $0,70 \mathrm{~m}$ between rows and five plants per linear meter. Only in the second and third agricultural cycles, corn was cultivated under no-tillage system, on the straw of the previous cycle.

Table 1. Physical and chemical characteristics of Yellow Latosol soil before the onset of the experiment, in a dystrophic Yellow Latosol

\begin{tabular}{|c|c|c|c|c|c|c|c|c|c|c|c|c|c|}
\hline Depth & $\begin{array}{c}\text { Coarse } \\
\text { Sand }\end{array}$ & $\begin{array}{l}\text { Thin } \\
\text { Sand }\end{array}$ & Silt & Clay & $\mathrm{C}$ & $\mathrm{pH}$ & $\mathrm{P}$ & K & $\mathrm{Ca}$ & $\mathrm{Mg}$ & $\mathrm{Al}$ & $\mathrm{H}+\mathrm{Al}$ & CEC \\
\hline$(\mathrm{cm})$ & ------- & $\mathrm{g} \mathrm{kg}^{-}$ & 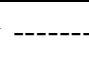 & ---- & $\mathrm{g} \mathrm{kg}^{-1}$ & $\left(\mathrm{H}_{2} \mathrm{O}\right)$ & & $\mathrm{kg}^{-1}$ & & 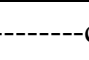 & 1 & . & ----- \\
\hline $0-20$ & 373 & 376 & 101 & 150 & 7.95 & 4.3 & 2 & 63 & 1.0 & 0.50 & 0.6 & 2.8 & 4.5 \\
\hline $20-40$ & 254 & 464 & 102 & 180 & 5.07 & 4.6 & 2 & 19 & 0.7 & 0.15 & 0.6 & 2.4 & 3.4 \\
\hline
\end{tabular}

C, Total organic carbon; CEC, Cation exchange capacity of soil.

In all experimental units, during the agricultural cycles, $\mathrm{N}, \mathrm{P}$ and $\mathrm{K}$ were applied using the recommendations established by Cravo et al. (2010). The fertilizers was applied at the rates of 120,90 and $90 \mathrm{~kg} \mathrm{ha}^{-1}$ of $\mathrm{N}, \mathrm{P}_{2} \mathrm{O}_{5}$ and $\mathrm{K}_{2} \mathrm{O}$, respectively, using urea, triple superphosphate, and potassium chloride.

Following the application of basic nutrients (NPK) in each agricultural cycle, soil samples were collected at 0-20 and 20-40 cm depths. The collected samples were air dried, for subsequent determination of the following chemical attributes: $\mathrm{P}$ and $\mathrm{K}$ was extracted by Mehlich-1 solution ( $\mathrm{HCl} 0.05 \mathrm{~mol} \mathrm{~L}^{-1}+\mathrm{H}_{2} \mathrm{SO}_{4} 0.0125 \mathrm{~mol} \mathrm{~L}^{-1}$ ); Soil $\mathrm{pH}$ was determined by electrode method at a 1:2.5 soil to water ratio. Exchangeable $\mathrm{Al}, \mathrm{Ca}$, and $\mathrm{Mg}$ were extracted with neutral $1 \mathrm{~mol} \mathrm{~L}^{-1} \mathrm{KCl}$ in a 1:10 soil/solution ratio. Aluminum (KCl-exchangeable acidity) 
was determined by titration with $0.025 \mathrm{~mol} \mathrm{~L}^{-1} \mathrm{NaOH}$ solution, and $\mathrm{Ca}$ and $\mathrm{Mg}$ by titration with $0.025 \mathrm{~mol} \mathrm{~L}^{-1}$ EDTA. Estimation of cation exchange capacity of soil (CEC) was calculated by adding the exchangeable cations $\left(\mathrm{Ca}^{2+}, \mathrm{Mg}^{2+}, \mathrm{K}^{+}\right)$and exchangeable acidity $\left(\mathrm{H}^{+}+\mathrm{Al}^{3+}\right)$. Percent base saturation $(\mathrm{V} \%)$ was calculated by the sum of bases ratio and CEC. All chemical attributes of the soil were analyzed according to the standard procedures described by Embrapa (2017).

In all agricultural cycles, corn was harvested at 120 days after sowing in a useful area corresponding to the four central lines of the experimental units. After harvesting, the ears were separated from the grains to determine the yield in $\mathrm{kg} \mathrm{ha}^{-1}$. Drying was performed in air until reaching a humidity of 13\% (Embrapa, 2000).

The results of the response variables were submitted to analysis of variance ( $\mathrm{F}$ test) and, when there was a significant effect of the treatments, the averages for the gypsum levels were compared using the Scott Knott test $(\mathrm{p} \leq 0,05)$ and for limestone levels, regression analysis was used.

\section{Results and Discussion}

\section{First agricultural cycle}

In the first cultivation cycle, soil $\mathrm{pH}$ and exchangeable $\mathrm{Al}$ were influenced only by the limestone vs. depth interaction, with significant effect only at the $0-20 \mathrm{~cm}$ depth. The $\mathrm{pH}$ (water) showed increasing linear behavior and the exchangeable Al contents decreased as the lime doses increased, indicating the effective neutralizing action of the concealer in the topsoil and the low mobility of the input in the soil profile (Figure 1).
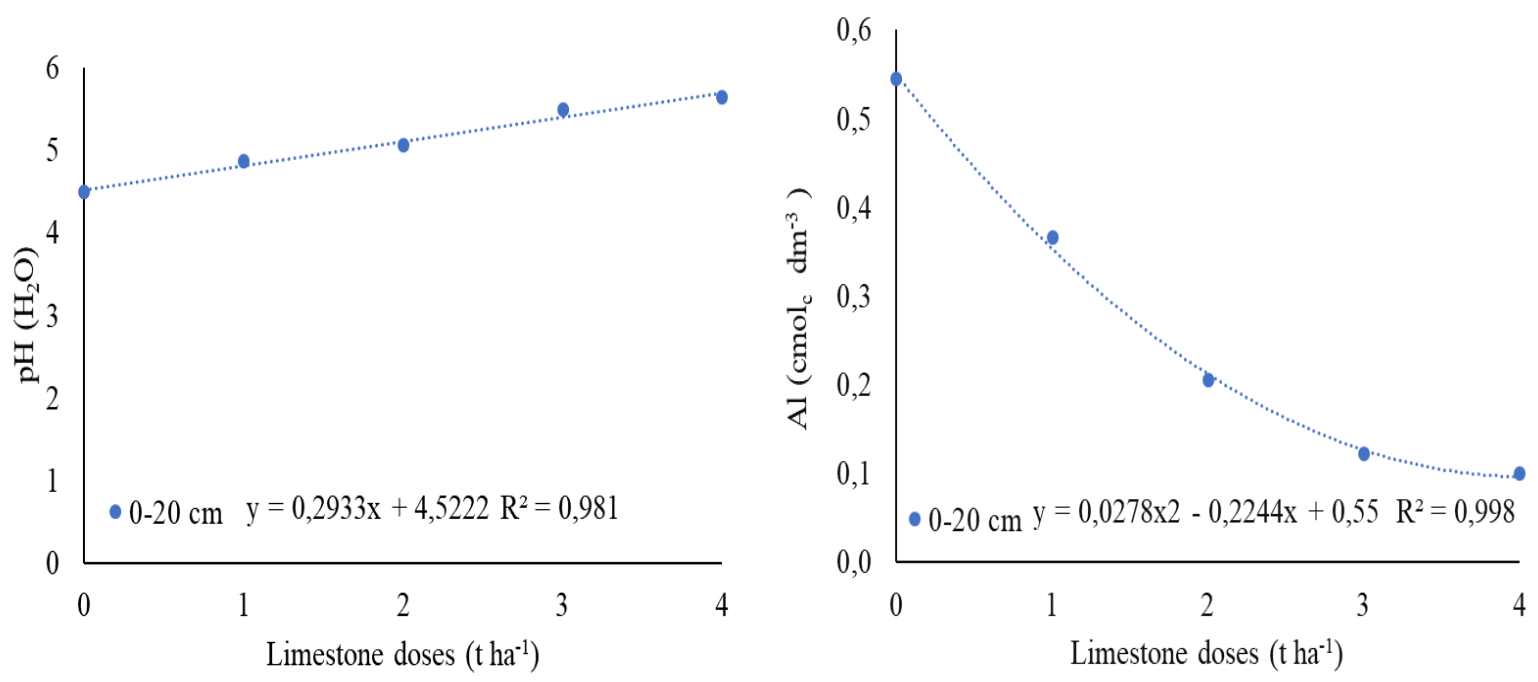

Figure 1. $\mathrm{pH}$ value e exchangeable $\mathrm{Al}$ content, as a function of the application of limestone at $0-20 \mathrm{~cm}$ depth

The increase in $\mathrm{pH}$ shows that limestone promoted improvements in this soil attribute only in the topsoil, which may have been caused by the dissociation of calcium carbonate, with hydroxyl release and $\mathrm{Fe}$ and $\mathrm{Al}$ precipitation in the form of $\mathrm{Fe}$ and $\mathrm{Al}$ hydroxide. Limestone 
dissociation in acidic environments is responsible for the release of anions $\left(\mathrm{OH}^{-}\right.$and $\left.\mathrm{HCO}_{3}{ }^{-}\right)$, which react with acidic cations of the soil solution $\left(\mathrm{H}^{+}, \mathrm{Al}^{3+}, \mathrm{Fe}^{2+}\right.$ and $\left.\mathrm{Mn}^{2+}\right)$, such correction results in the movement of basic cations over the soil profile. Another factor that contributed to the movement of bases was proper soil structure, adequate rainfall which favors the movement over the soil profile. In addition, biopores formed by the root system and organisms may also favor the movement in areas under NTS. The increase in soil pH through liming increases basic cation retention due to the increase in negative variable electric charges, which are generated on the surface of colloids by the dissociation of $\mathrm{H}^{+}$from the hydroxyl groups. Exchangeable $\mathrm{Ca}^{2+}$ and $\mathrm{Mg}^{2+}$ levels increased with the liming.

The action of limestone on soil pH-related improvements is already known due to the increase in $\mathrm{OH}^{-}$in soil solution caused by the reaction of calcium carbonate with water, which contributes to the reduction in exchangeable $\mathrm{Al}$ activity and increases in $\mathrm{Ca}^{2+}$ and $\mathrm{Mg}^{2+}$ contents, promoting the development of the root system and, consequently, improvement in the absorption of the supplied nutrients, which is the most effective action in the most superficial soil layers. Bortolanza; Klein (2016) and Crusciol et al. (2016) found an increase in topsoil $\mathrm{pH}$ after calcium carbonate application, which is related to the efficiency of the action in the topsoil due to its low mobility rate in the soil. Shamshuddin \& Fauziah (2010) found results similar results to those found in this work. Those authors found a decrease in $\mathrm{Al}^{3+}$ toxicity after limestone application.

Values of $\mathrm{Ca}^{2+}, \mathrm{Ca}+\mathrm{Mg}, \mathrm{CEC}$ and $\mathrm{V} \%$ in the soil were significantly influenced by limestone vs. gypsum interaction. The application of limestone combined with gypsum promoted the increase in exchangeable $\mathrm{Ca}^{2+}$ (Figure $2 \mathrm{a}, 2 \mathrm{~b}$ ) and $\mathrm{Ca}+\mathrm{Mg}(2 \mathrm{c}, 2 \mathrm{~d}$ ) contents in the soil, and the largest increments were found in the topsoil. These results indicate that the increases in the contents of these nutrients in the depth were due to the application of gypsum, which promoted the movement of these bases through the soil profile when compared to the treatment without gypsum (Figure $2 \mathrm{a}$ and Figure 2c). The response surfaces of $\mathrm{Ca}^{2+}$ and $\mathrm{Ca}+$ $\mathrm{Mg}$ contents in the soil as a function of lime and gypsum doses, in the 20-40 cm depth (Figures $2 \mathrm{~b}$ and $2 \mathrm{~d}$ ), show that there was a reduction of $\mathrm{Ca}^{2+}$ and $\mathrm{Ca}+\mathrm{Mg}$ contents with the application of the highest amounts of limestone, indicating that these bases may have moved to layers below $40-\mathrm{cm}$ depth.

Considering the response surface models adopted for the $\mathrm{Ca}^{2+}$ and $\mathrm{Ca}+\mathrm{Mg}$ contents, as a function of the combined doses of limestone and gypsum, the maximum contents of these bases were obtained with the application of $3.99\left(\mathrm{Ca}^{2+}\right)$ and $2.21(\mathrm{Ca}+\mathrm{Mg}) \mathrm{t} \mathrm{ha}^{-1}$ of limestone, together with $0.5 \mathrm{t} \mathrm{ha}^{-1}$ of gypsum, respectively, at the 0-20 and 20-40 cm depths. With these regression models, the application of these amount of limestone and plaster raised the levels of $\mathrm{Ca}^{2+}$ and $\mathrm{Ca}+\mathrm{Mg}$ in the soil from 1.03 and $1.50 \mathrm{cmol}_{\mathrm{c}} \mathrm{dm}^{-3}$ (without application of inputs) to 1.90 and $3.17 \mathrm{cmol}_{\mathrm{c}} \mathrm{dm}^{-3}$ at the same depths.

The supply of Ca by means of gypsum application improved both the topsoil and subsurface layers, promoting significant enhancements through cation transport. The increase in basic cations in subsurface soil layers is directly linked to gypsum related functions. Due to its high solubility and the release of sulfate ions in the soil solution, this conditioner is responsible for 


\section{Macrothink Institute ${ }^{T M}$}

the transport of bases in the profile, promoting improvements in these layers. $\mathrm{Ca}^{2+}$ contents found in the 20-40 cm layer presented values in all applied doses above $1 \mathrm{cmol}_{\mathrm{c}} \mathrm{dm}^{-3}$, thus demonstrating that the application of lime-based agricultural gypsum is promoting the movement of this nutrient to the soil subsurface layers, which may indicate an improvement in the deeper soil layers. Rodrighero et al., (2015), when evaluating the superficial application under no-tillage system, where an improvement of $\mathrm{Mg}$ contents were observed in the soil profile, due to the formation of $\mathrm{MgSO}_{4}{ }^{0}$ complex, which has high mobility in the soil. Similar results were also found by Briedis et al., (2012), when evaluating areas under no-tillage systems observed improvements in this attribute in the topsoil, with reduction as depth was increased.

\section{$c a=0,9956+0,3467^{*} x+0,3506^{*} y-0,1733^{*} x^{*} x+1,0721 E-15^{*} x^{*} y-0,0417^{*} y^{*} y$}

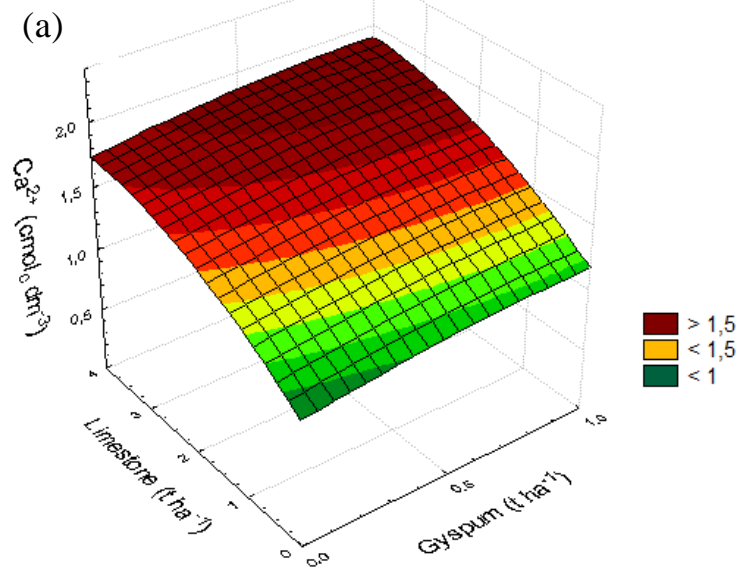

$\mathrm{Ca}=0,5846+0,2663^{\star} x+0,1475^{\star} y+0,0803^{\star} x^{*} x-0,0033^{*} x^{*} y-0,0322^{*} y^{*} y$

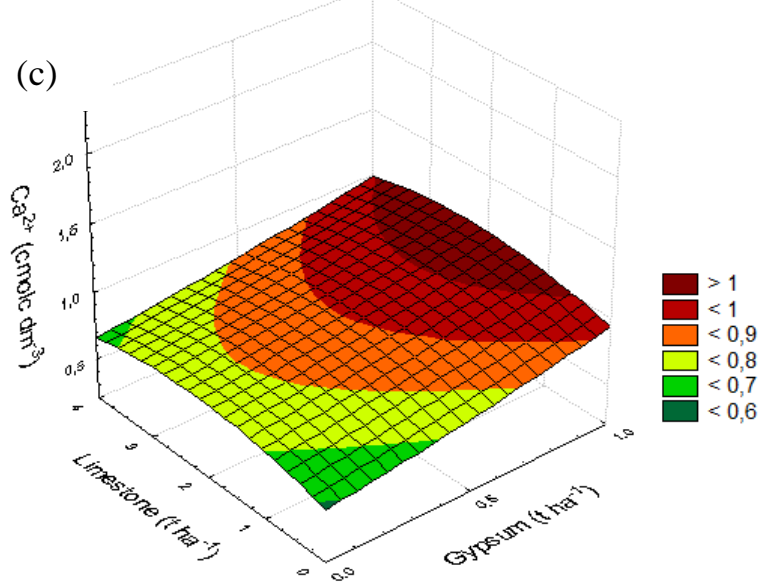

$c a+m g=1,4371+0,6467^{*} x+0,2907^{*} y-0,5333^{*} x^{*} x+0,0267^{*} x^{*} y+0,0202^{*} y^{*} y$

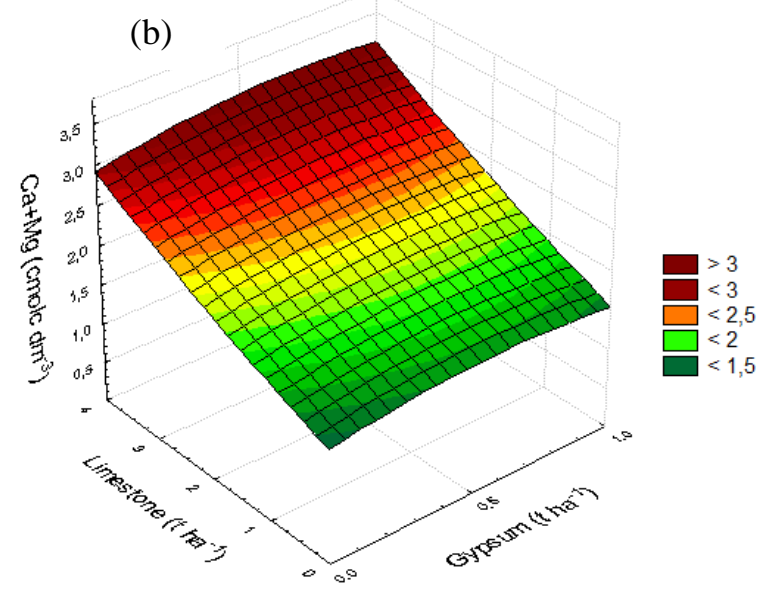

$c a+m g=0,7155+0,6298^{*} x+0,3565^{*} y-0,1062^{*} x^{*} x-0,0083^{*} x^{*} y-0,0731^{*} y^{*} y$

(d)

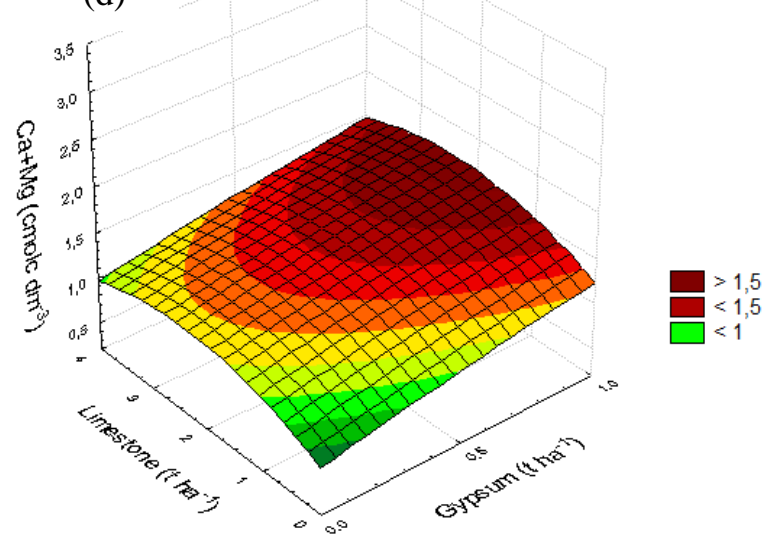

Figure 2. $\mathrm{Ca}^{2+}$ and $\mathrm{Ca}+\mathrm{Mg}$ contents, as a function of the application of limestone and gypsum at $0-20 \mathrm{~cm}$ (a and c) and 20-40 cm depths (b and d)

Regardless of the gypsum dose, the application of limestone promoted a slight increase in the CEC in the topsoil $(0-20 \mathrm{~cm})$; however at the $20-40 \mathrm{~cm}$ depth, no significant effect of the application of these inputs (Figures 3a, 3b) was observed. 


\section{Macrothink Institute ${ }^{T M}$}

The base saturation (V\%) presented similar behavior to the $\mathrm{Ca}+\mathrm{Mg}$ content, in response to the combined application of limestone and gypsum, with an increase in the values as the applied quantities of the inputs increased (Figure $4 \mathrm{a}$ and $4 \mathrm{~b}$ ). In the topsoil, V\% linearly increased due to the application of limestone, but no significant difference was observed between the amount of gypsum and the control treatment (without gypsum). At the $20-40 \mathrm{~cm}$ depth, the application of gypsum $(0.5$ and $1 \mathrm{t})$ promoted the reduction in V\% indices in the larger amounts of limestone, indicating a possible movement of bases in the soil profile towards deeper layers. Considering the need to improve the V\% index of the subsurface soil through the application of gypsum and following the response surface models, the amounts of limestone and gypsum needed to achieve the highest $\mathrm{Ca}+\mathrm{Mg}$ contents in the soil allow $\mathrm{V} \%$ to rise to $68 \%$.

Based on the values obtained for $\mathrm{V} \%$, it is evident that the contribution of limestone and gypsum for the improvement of the chemical characteristics of the soil. The highest $\mathrm{Ca}$ and $\mathrm{Mg}$ contents previously found positively influenced the V\% of the soil, also demonstrating the effect of vertical movement of the bases over the soil profile.

cec $=4,6091+0,6009^{*} x+0,1736^{*} y-0,2613^{*} x^{*} x-0,1314^{*} x^{*} y-0,0088^{*} y^{*} y$

(a)

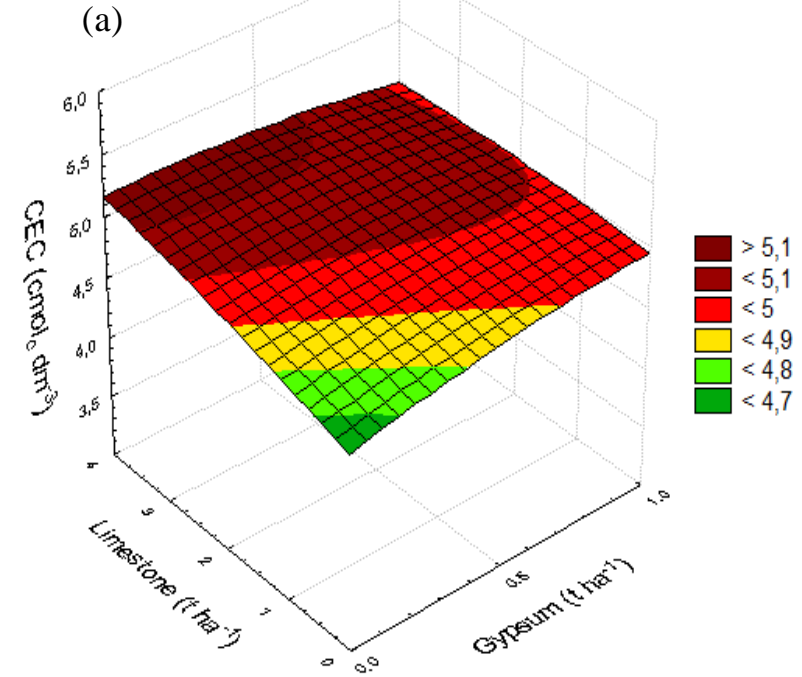

cec $=3,2102+1,1048^{*} x+0,4413^{*} y-0,335^{*} x^{*} x-0,1373^{*} x^{*} y-0,069^{*} y^{*} y$

(b)

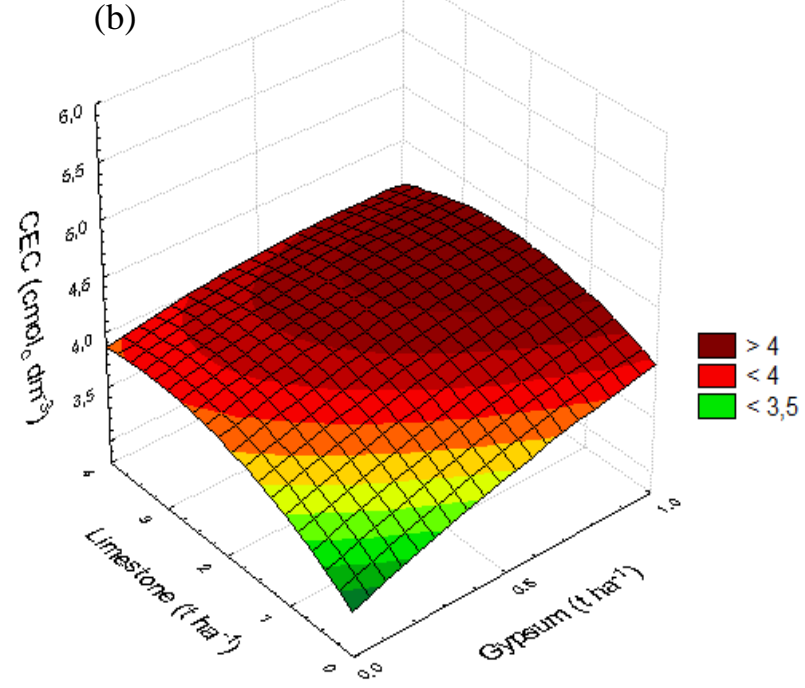

Figure 3. CEC values as a function of lime and gypsum application at 0-20 cm (a) and 20-40 $\mathrm{cm}(\mathrm{b})$ 
$v \%=48,6391-10,5977^{*} x-2,1418^{*} y+0,4171^{*} x^{*} x+4,4338^{*} x^{*} y+0,7257^{*} y^{*} y$

(a)

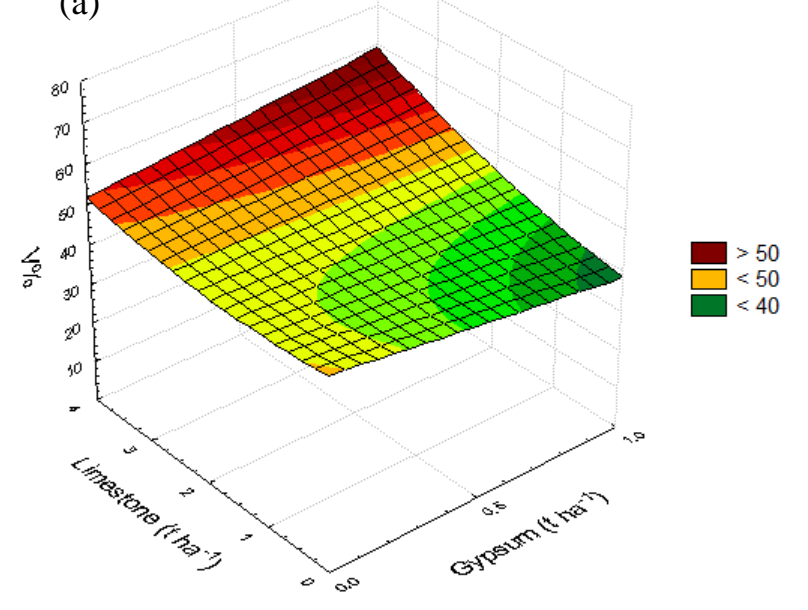

$v \%=27,2793+5,0293^{*} x+7,9622^{*} y-4,7075^{\star} x^{\star} x-1,8462^{*} x^{*} y-1,0852^{*} y^{*} y$

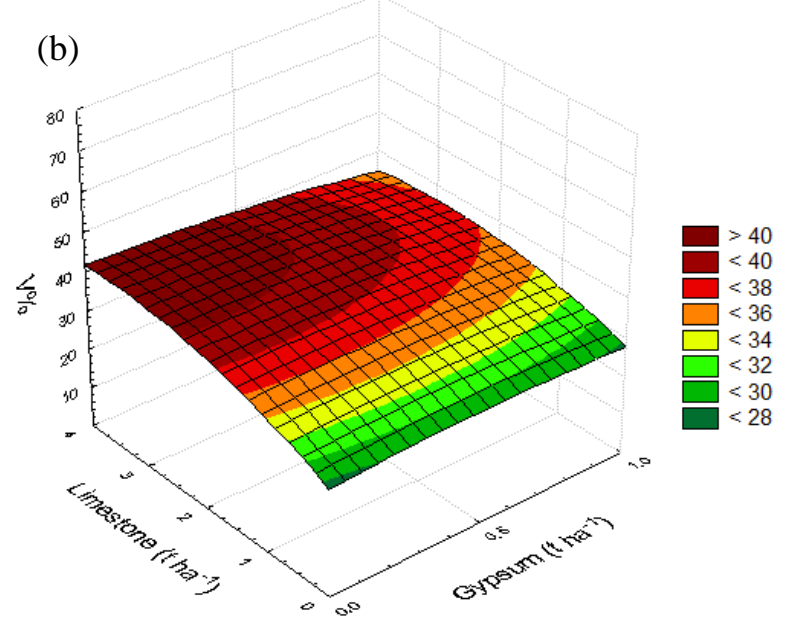

Figure 4. V\% as a function the application of limestone and gypsum at 0-20 cm (a) and 20-40 cm depths (b)

In the first agricultural cycle of the experiment, corn yield was influenced only by limestone, showing an increasing linear behavior of grain yield, as the applied doses increased (Figure 5 ). The increase in corn grain production was associated with the reduction of acidity found in the topsoil, with an increase in $\mathrm{pH}$ and reduction in exchangeable $\mathrm{Al}$, as well as the increase in $\mathrm{Ca}^{2+}$ and $\mathrm{Ca}+\mathrm{Mg}$ contents caused by limestone application. Although the application of gypsum promoted an increase in the levels of these chemical bases in the subsurface layer of the soil, it did not reflect on the corn grain yield, indicating that the improvement in the topsoil fertility promoted by limestone was sufficient to guarantee increases in the soil crop yield.

The increase in essential macronutrient contents in the soil solution as a function of the supply of basic cations, increased their absorption as a consequence of the adequate nutritional status. We obtained positive reflexes on the corn grain yield, with an increase in limestone doses. When evaluating an experiment with sequential cultivation of crop (2000-2001), soybean (2001-2003) and wheat (2003), Caires et al. (2008) found no improvement in corn and soybean grain yield after surface liming, while the application of soil amendment treatment also provided improvements in wheat grain yield, which is related to this improvement due to the supply of bases and possibly the best environment for root growth with the possibility of greater nutrient absorption due to the larger coverage area.

Caires et al. (2004) evaluating maize responses as a function of limestone and gypsum application found that the combined use of conditioners was responsible for a $17 \%$ increase in maize production. These results demonstrate that the combined use of plaster and dolomitic limestone may promote significant increases in corn production. 


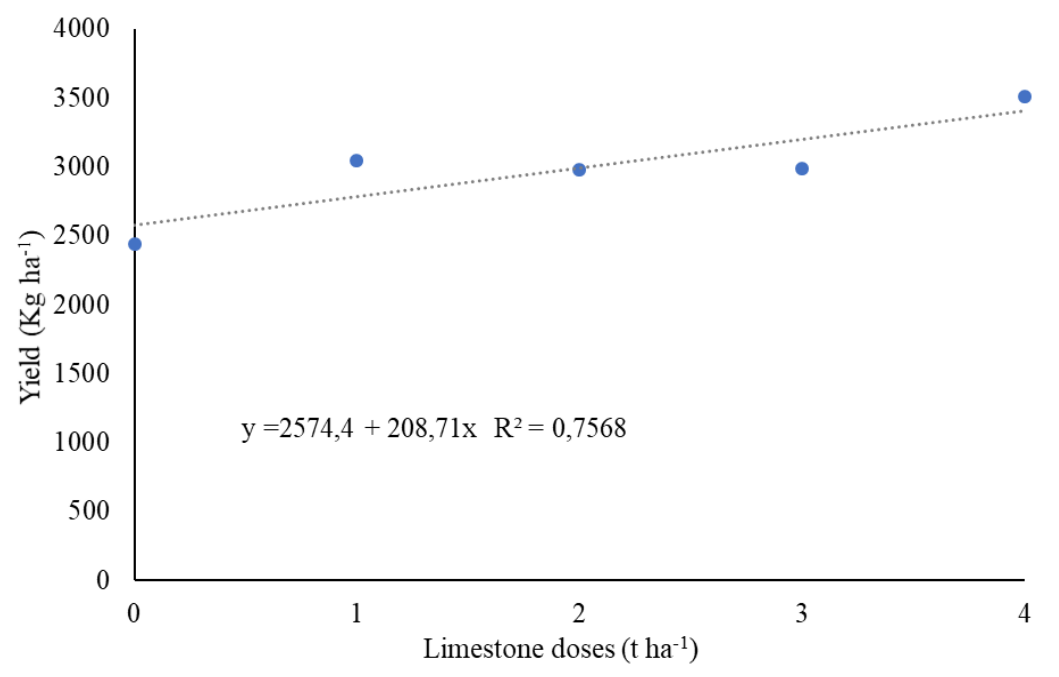

Figure 5. Corn yield as a function the application of limestone

Considering that the maximum $\mathrm{Ca}+\mathrm{Mg}$ contents were obtained with the application of $4 \mathrm{t}$ $\mathrm{ha}^{-1}$ of limestone, it can be inferred that the optimum corn grain yield obtained with this amount of concealer was equivalent to $3516 \mathrm{~kg} \mathrm{ha}^{-1}$.

\section{Second agricultural cycle}

The second year of corn cultivation was conducted under no-tillage system, without application of limestone and gypsum. In this condition, it is possible to observe the occurrence of residual effect of limestone and gypsum on the chemical attributes linked to soil acidity. Liming provided significant increases in $\mathrm{pH}$ (Figure 6), exchangeable $\mathrm{Ca}+\mathrm{Mg}$ and base saturation, as well as significantly reducing the contents of exchangeable Al (Figure 7), in the two depths evaluated. High liming action was noticed in the increase of exchangeable $\mathrm{pH}, \mathrm{Ca}^{2+}$ (Figure 8a), $\mathrm{Ca}+\mathrm{Mg}$ (Figure 8b), CEC (Figure 9) and base saturation (Figure 10) and in the reduction of potential acidity, up to $20 \mathrm{~cm}$ deep, in the sampling carried out 12 months after application These results indicate that liming dissociation was responsible for increasing nutrient content as well as complexing $\mathrm{Al}^{3+}$.

The limestone action at a depth of $20-40 \mathrm{~cm}$ did not have the same effect when compared to a depth of $0-20$. The action of this conditioning in neutralizing the acidity of the subsoil is prevented by the increase in the retention of cations due to the formation of negative variable charges with the increase of the $\mathrm{pH}$ of the soil. With this, anions resulting from this dissolution, responsible for the correction of acidity, are consumed in reactions with other acid cations $\left(\mathrm{Al}^{3+}, \mathrm{Mn}^{2+}\right.$ and $\left.\mathrm{Fe}^{2+}\right)$ in the deposition layer of the limestone. However, the increase in $\mathrm{pH}$ at the soil surface can accelerate the speed with which $\mathrm{HCO}_{3}{ }^{-}$, accompanied by $\mathrm{Ca}$ and $\mathrm{Mg}$, percolates underground to react with exchangeable Al in deep layers. The movement of exchangeable $\mathrm{Ca}+\mathrm{Mg}$ in the soil and the reduction of exchangeable $\mathrm{Al}$ in the subsoil can also be related to the leaching mechanism proposed by Tiritan et al., (2016), through the formation of water-soluble organic complexes present in the remains of plants.

The increase in $\mathrm{pH}$, as well as an increase in the levels of $\mathrm{Ca}^{2+}, \mathrm{Ca}+\mathrm{Mg}, \mathrm{CEC}$ and $\mathrm{V} \%$ in the 


\section{Macrothink}

second agricultural cycle following the use of correctives is caused by the increment in the in hydroxyl concentration and the reduction in $\mathrm{H}^{+}$concentration in the soil solution (Oliveira; Pavan, 1996). Thus, it is evident in this study from the results found, it is clear that the gypsum does not participate in the correction of soil acidity, which has been found in several studies in the literature (Ramos et al., 2013).

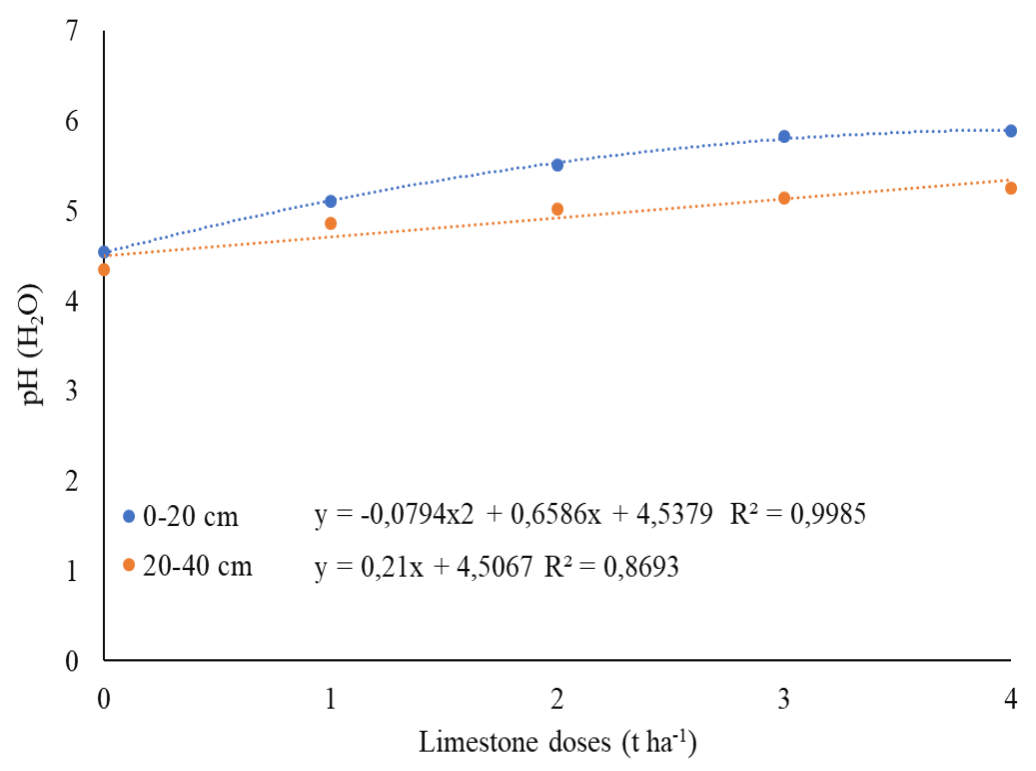

Figure 6. $\mathrm{pH}$ values, as a function of the application of limestone at $0-20 \mathrm{~cm}$ depth and 20-40 $\mathrm{cm}$

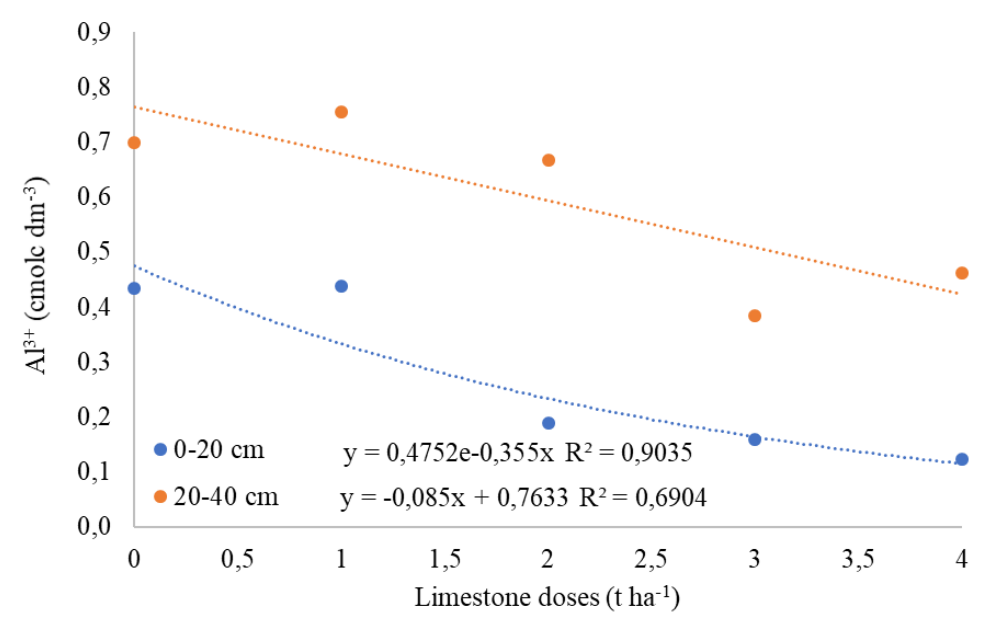

Figure 7. Exchangeable $\mathrm{Al}$ contents, as a function of limestone application at $0-20 \mathrm{~cm}$ and 20-40 cm depths

The $\mathrm{Ca}^{2+}$ contents in soil as a function of limestone doses in the $0-20 \mathrm{~cm}$ depth showed higher contents when compared to the $20-40 \mathrm{~cm}$ depth, indicating that there was a reduction as a function of depth as the product was more restricted to the surface layer $(0-20 \mathrm{~cm})$ 


\section{$\triangle$ Macrothink}

(Figure 8a). With the regression models, the application of this amount of limestone allowed the levels of $\mathrm{Ca}^{2+}$ and $\mathrm{Ca}+\mathrm{Mg}$ in the soil to increase from 1.52 and $1.77 \mathrm{cmol}_{\mathrm{c}} \mathrm{dm}^{-3}$ (without application of the input) to 2.16 and $3.15 \mathrm{cmol}_{\mathrm{c} \mathrm{dm}} \mathrm{dm}^{-3}$ at the same depth (Figure 8b). Regression models followed for $\mathrm{Ca}^{2+}$ and $\mathrm{Ca}+\mathrm{Mg}$ contents as a function of limestone doses, the maximum levels of these bases were reached with the application of $4 \mathrm{t} \mathrm{ha}^{-1}$ limestone at both depths. The increase in basic cations in subsurface soil layers is directly linked to gypsum related functions. Due to its high solubility and the release of sulfate ions in the soil solution, this conditioner is responsible for the transport of bases in the profile, promoting improvements in these layers.

Some studies report that the increase in exchangeable $\mathrm{Ca}^{2+}$ content in the soil with lime and gypsum supply occurs as both are sources of $\mathrm{Ca}^{2+}$, therefore, it is possible to observe the increase in $\mathrm{Ca}$ contents in the soil profile from the applied treatments (Caires; Joris; Churka, 2011). However, $\mathrm{Ca}^{2+}$ contents found in the $20-40 \mathrm{~cm}$ layer presented values in all applied doses above $1 \mathrm{cmolc}^{-3}$, thus demonstrating that the application of lime-based agricultural gypsum is promoting the movement of this nutrient to the soil subsurface layers, which may indicate an improvement in the deeper soil layers. Similar results were found by Nora et al. (2017) in experiments under no-tillage system, in which the authors observed higher $\mathrm{Ca}^{2+}$ content in the topsoil after application of limestone and agricultural gypsum, which was attributed to the low mobility of this nutrient in the soil.
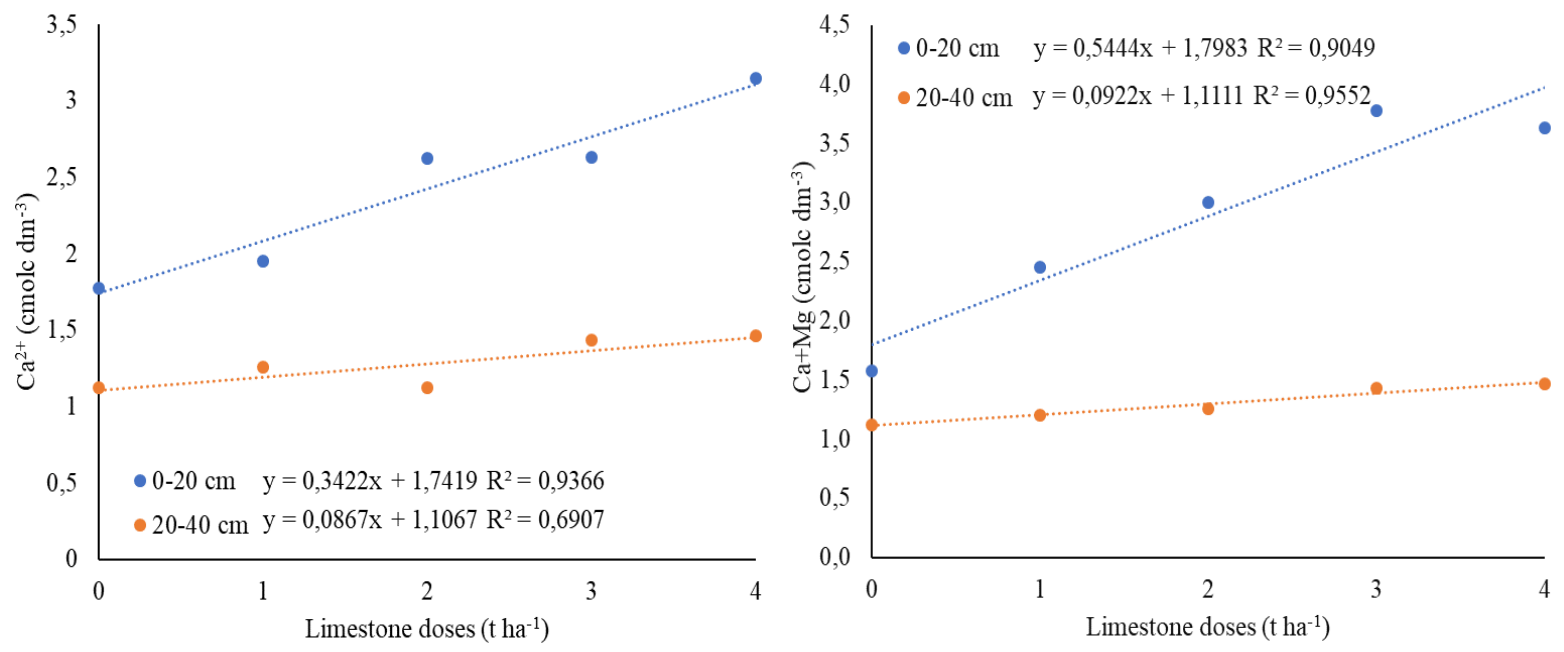

Figure $8 . \mathrm{Ca}^{2+}$ (a) and $\mathrm{Ca}+\mathrm{Mg}$ (b) contents, as a function of the application of limestone at 0-20 $\mathrm{cm}$ and $20-40 \mathrm{~cm}$ depths

Soil CEC was influenced by the factors considered Limestone in both depths. Based on the followed models as a function of limestone and gypsum doses, the increase in CEC was achieved with the application of 2.70 and $2.12 \mathrm{tha}^{-1}$ of limestone, combined with $0.5 \mathrm{t} \mathrm{ha}^{-1}$ of gypsum for the 0-20 $\mathrm{cm}$ and 20-40 $\mathrm{cm}$ depths, respectively (Figure 9). 


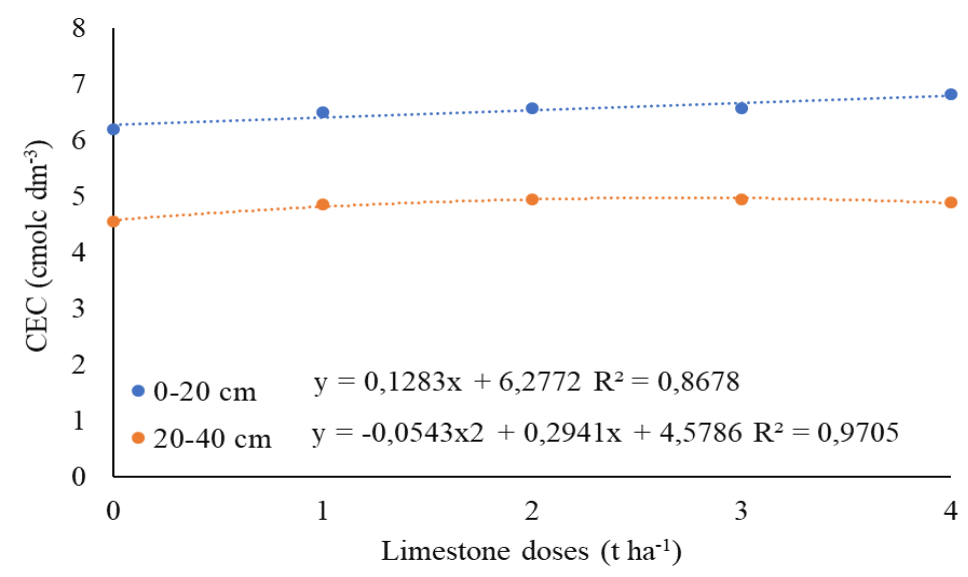

Figure 9. CEC values as a function of lime application at $0-20 \mathrm{~cm}$ (a) and $20-40 \mathrm{~cm}$

$\mathrm{V} \%$ increased due to the isolated doses of lime and gypsum doses, where an increase was observed in the levels as the applied quantities of the inputs increased (Figure 10). In the 0-20 $\mathrm{cm}$ layer, the isolated application of $4 \mathrm{t}$ of limestone and $1 \mathrm{t}$ of gypsum promoted a significant increase of $\mathrm{V} \%$, indicating that the higher dose applied, as well as the longer duration of the conditioners, contributed to the increase of this index.

Regarding V\%, similar results were found by Joris et al. (2013), when evaluating the application of gypsum and limestone. Those authors found that the improvement in V\% was concentrated in the first $20-\mathrm{cm}$ depth, which may be related, in part, to the high extraction of nutrients by plants or to the short period for promotion of improvements in chemical attributes after the application of soil amendments. Based on the values obtained for $\mathrm{V} \%$, it is evident that the contribution of limestone and gypsum for the improvement of the chemical characteristics of the soil. The highest $\mathrm{Ca}$ and $\mathrm{Mg}$ contents previously found positively influenced the V\% of the soil, also demonstrating the effect of vertical movement of the bases over the soil profile.
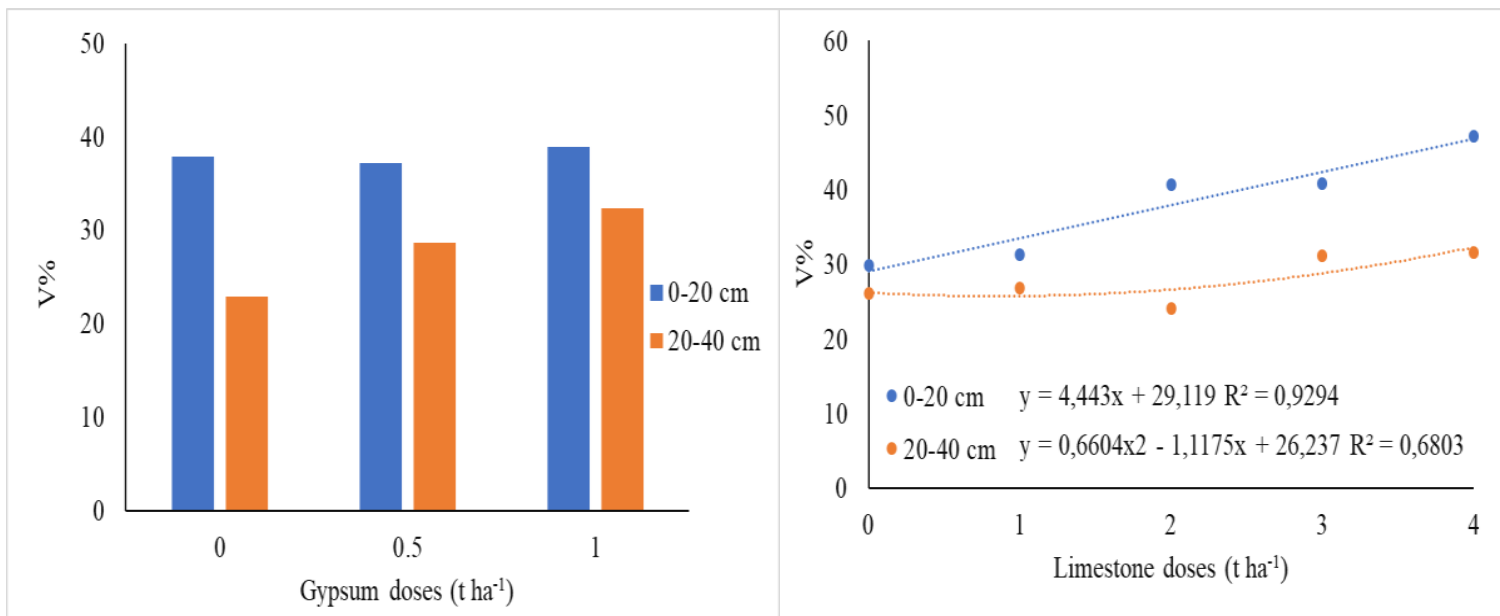

Figure 10. V\% as a function of application of gypsum at the $0-20 \mathrm{~cm}$ and $20-40 \mathrm{~cm}$ depths (a) and application of limestone at $0-20 \mathrm{~cm}$ and $20-40 \mathrm{~cm}$ depths (b) 


\section{Al Macrothink Institute ${ }^{\mathrm{TM}}$}

Corn yield in the second agricultural cycle of the experiment was influenced by limestone vs. gypsum, showing increasing linear grain yield as the applied doses increased (Figure 11). The increase in grain yield is a reflection of the increase promoted by the conditioners, such as $\mathrm{pH}$, reduction of exchangeable $\mathrm{Al}^{3+}$, as well as increase of $\mathrm{Ca}^{2+}$ and $\mathrm{Ca}+\mathrm{Mg}$ levels, due to the application of limestone and gypsum. The action of the gypsum in the layers below $20 \mathrm{~cm}$ was observed due to the increase of the contents of these bases in these layers.

From the response surface (Figure 11) it was possible to find the maximum levels of $\mathrm{Ca}^{2+}$ $\left(2.16 \mathrm{cmol}_{\mathrm{c}} \mathrm{dm}^{-3}\right)$ and $\mathrm{Ca}+\mathrm{Mg}\left(3.15 \mathrm{cmol}_{\mathrm{c}} \mathrm{dm}^{-3}\right)$ were obtained through the application of $3.24 \mathrm{t} \mathrm{ha}^{-1}$ of limestone, which promoted maximum production of corn grains. Based on the basic cation contents observed as a function of limestone application, the equivalent of 5331 $\mathrm{kg} \mathrm{ha}^{-1}$ of corn grains was obtained. Soratto et al. (2010), when evaluating the productivity of higher lands beans and rice as a function of surface application of limestone and gypsum, also found an increase in grain yield as a function of applied doses, unlike the results found by Neis et al. (2009), when evaluating soybean yield in no-tillage system with and without soil plowing, obtained higher yield in the no-tillage system. Nevertheless, there was no influence by gypsum doses. In addition, this improvement was related to the adequate nutrient content found in the soil.

\section{Yield $=3600,512+4,0179^{*} x+456,6583^{*} y+775,1488^{*} x^{*} x-29,0551^{*} x^{*} y-27,1932^{*} y^{*} y$}

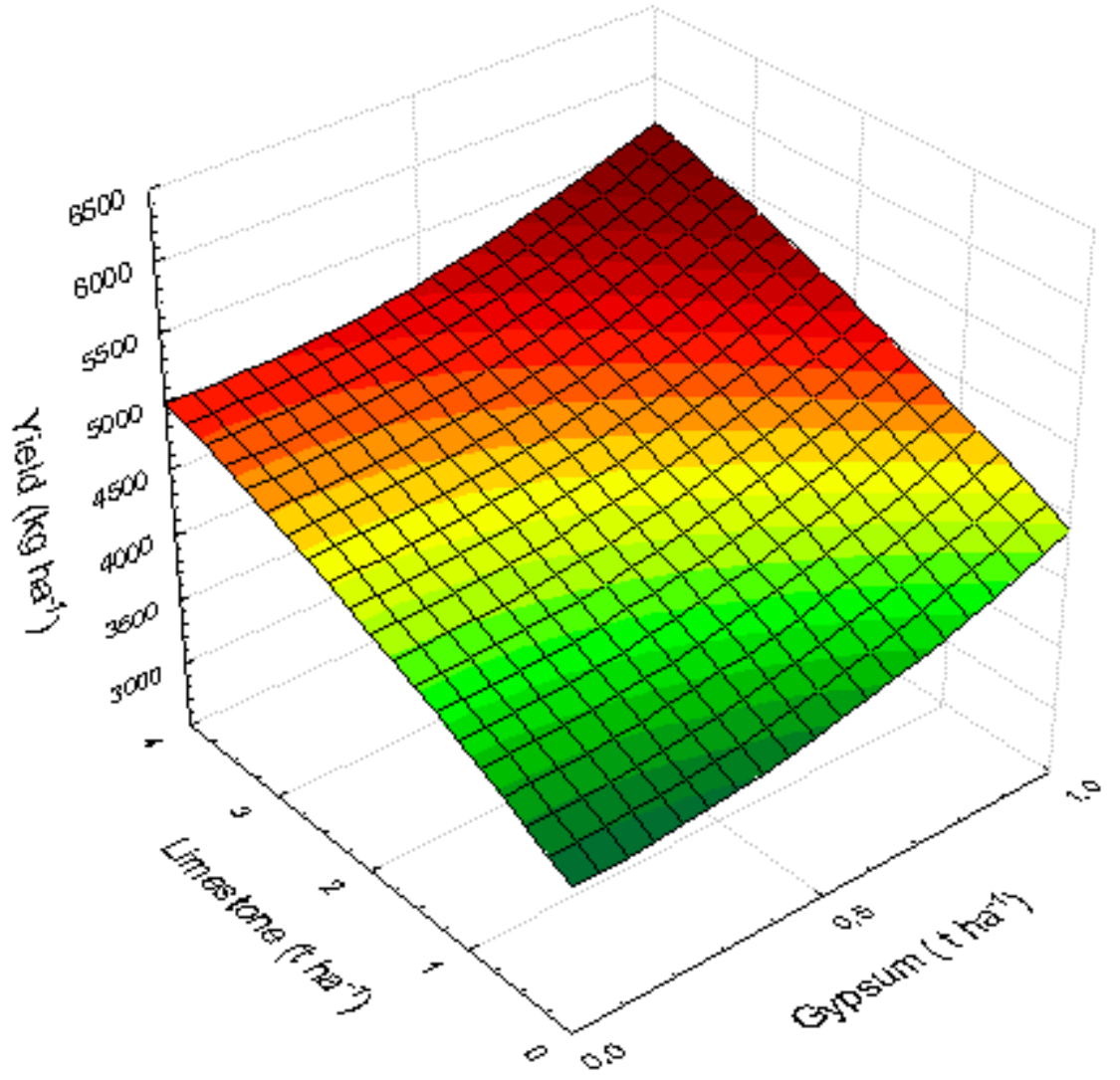

Figure 11. Corn grain yield due to limestone and gypsum application in the second agricultural cycle. 


\section{Mll Macrothink}

\section{Third agricultural cycle}

The third year of corn cultivation was also conducted under no-tillage system, with no soil tillage, without application of limestone and gypsum. In this condition, it was observed the residual effect of limestone and gypsum on chemical attributes linked to soil acidity. Soil $\mathrm{pH}$ (water) was influenced by the interaction between limestone vs. depth, with significant effect on the $0-20 \mathrm{~cm}$ and 20-40 cm depths (Figure 12). The soil collection carried out 24 months after the application of lime was found that the $\mathrm{pH}$ of the two depths evaluated were similar. However, there is a front of acidity correction and base migration in depth $(20-40 \mathrm{~cm})$, even without the incorporation of limestone, which was more pronounced with time after application. Similar results were obtained by Caires et al. (2001), in a dystrophic Red Latosol medium texture, with increased $\mathrm{pH}$ and decreased exchangeable acidity up to $20 \mathrm{~cm}$, after 12 months of liming, reaching up to $60 \mathrm{~cm}$ after 68 months.

In the no-tillage system, the permanence of organic residues in the soil cover reduces variations in temperature and humidity, this can contribute to the fauna responsible for opening continuous channels, through which there may be movement of the superficially applied limestone (Oliveira \& Pavan, 1996), as well as it can also continuously activate water-soluble organic substances that move along the soil profile and can act as $\mathrm{Ca}^{2+}$ and $\mathrm{Mg}^{2+}$ carriers, acting as ligands or ionic pairs, facilitating their distribution in the profile. These openings left by dead roots and the natural cracking of the soil contribute to the displacement of fine particles, along with the downward movement of water.

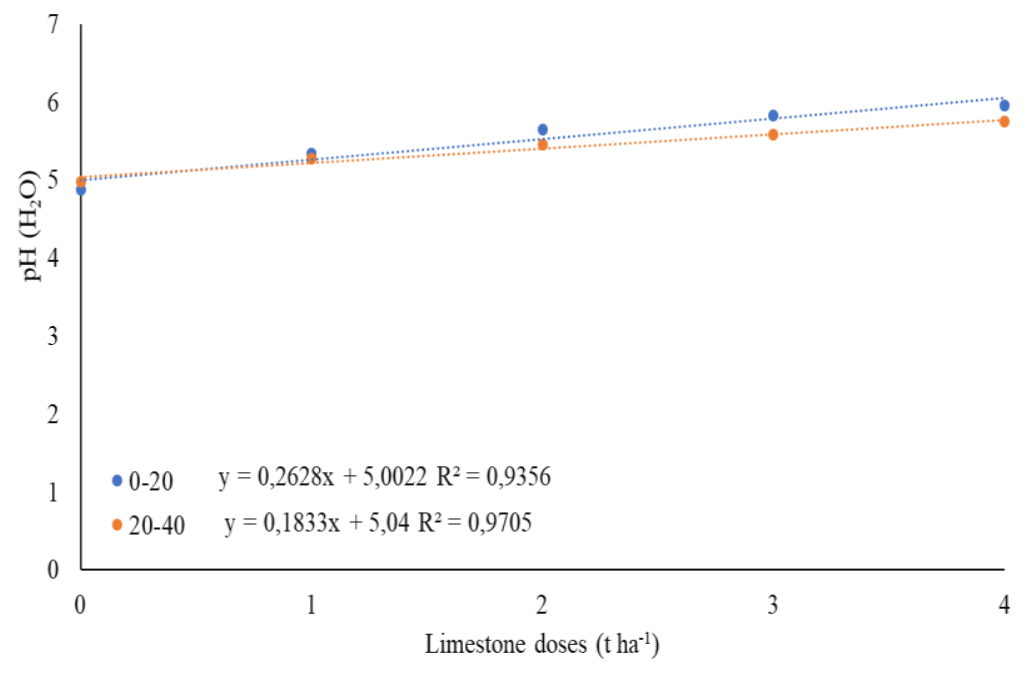

Figure 12. $\mathrm{pH}$ values, as a function of the application of limestone at $0-20 \mathrm{~cm}$ depth and

$$
20-40 \mathrm{~cm}
$$

The levels of exchangeable $\mathrm{Al}^{3+}$ decreased $\left(\mathrm{y}_{(\mathrm{Al})}=0.7399+0.4565-0.0758 \mathrm{x}^{2} \mathrm{R}^{2}=0.97\right)$ due to the increase in doses of limestone, so, it can be inferred that the effective action of the applied product occurs in the topsoil as a function of the slow input mobility in the soil profile. There was also an effect of the interaction plaster vs. depth, which was responsible 


\section{Macrothink}

Journal of Agricultural Studies

ISSN 2166-0379

2020, Vol. 8, No. 3

for the transport of bases over the profile which also favored the aluminum complexation, thus reducing its activity in this layer.

The attributes $\mathrm{Ca}^{2+}, \mathrm{Ca}+\mathrm{Mg}, \mathrm{CEC}$ and $\mathrm{V} \%$ of the soil were significantly influenced by the lime vs. depth interaction. The application of limestone promoted an increase of exchangeable $\mathrm{Ca}^{2+}$ and $\mathrm{Ca}+\mathrm{Mg}$ contents in the soil; however the largest increments were verified in the topsoil $(0-20 \mathrm{~cm})$ (Figure 13a, 13b). Such results indicate that the action of the limestone is limited in this soil range. Based on those regression models, the application limestone allowed the $\mathrm{Ca}^{2+}$ and $\mathrm{Ca}+\mathrm{Mg}$ contents in the soil to rise from 1.25 and $1.08 \mathrm{cmol}_{\mathrm{c}}$ $\mathrm{dm}^{-3}$ to 2.78 and $4.12 \mathrm{cmol}_{\mathrm{c}} \mathrm{dm}^{-3}$ respectively at a $0-20 \mathrm{~cm}$ depth. Soil CEC was influenced only by the limestone doses, however, the $0-20 \mathrm{~cm}$ layer was the one with the highest increase when compared to the layer below (Figure 14).
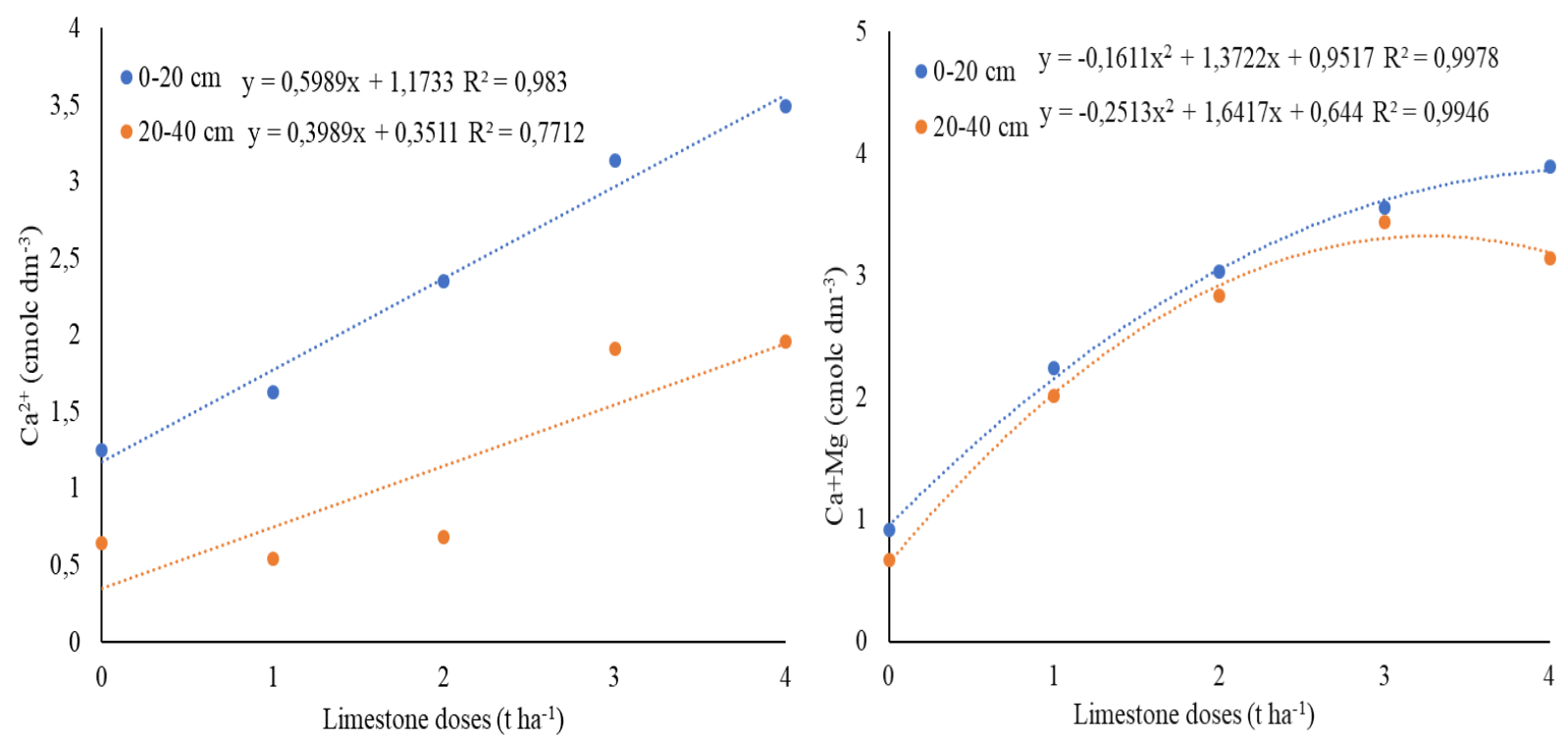

Figure 13: $\mathrm{Ca}^{2+}(\mathrm{a})$ and $\mathrm{Ca}+\mathrm{Mg}(\mathrm{b})$ contents as a function of limestone application 


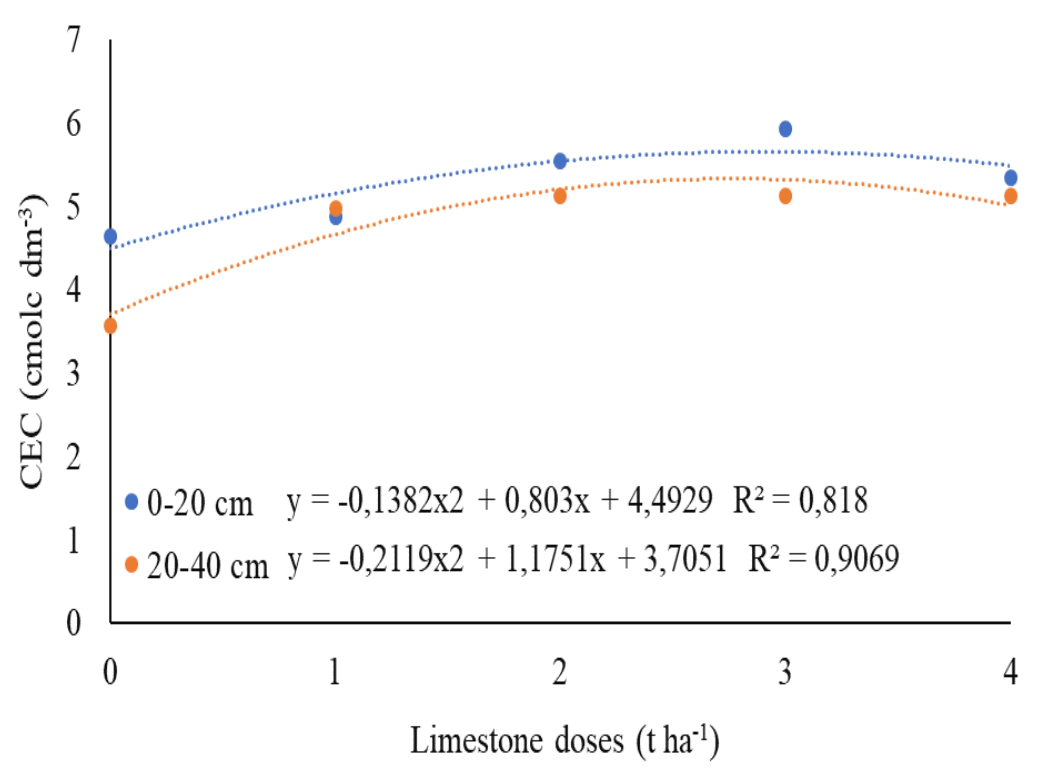

Figure 14. CEC contents as a function of lime application at 0-20 cm and 20-40 cm dephts.

An increase was observed for V\% in the two depths evaluated in the study in response to the isolated application of limestone and gypsum (Figure 15). It showed a more significant increase in the topsoil, presenting expressive difference between the quantities of limestone and the control treatment in the 0-20 cm depth. In the 20-40 cm depth, the application of limestone also promoted increment, but in a smaller scale, due to the restriction of action of the applied input. Gypsum applied alone presented greater increase also in the topsoil, however, the increment of the bases in these layers may be more associated with the influence of limestone. However, it was noticed that the $20-40 \mathrm{~cm}$ layer had lower base saturation, and it can be inferred from these results that the application of gypsum was responsible for this transport to the layers below $40 \mathrm{~cm}$.

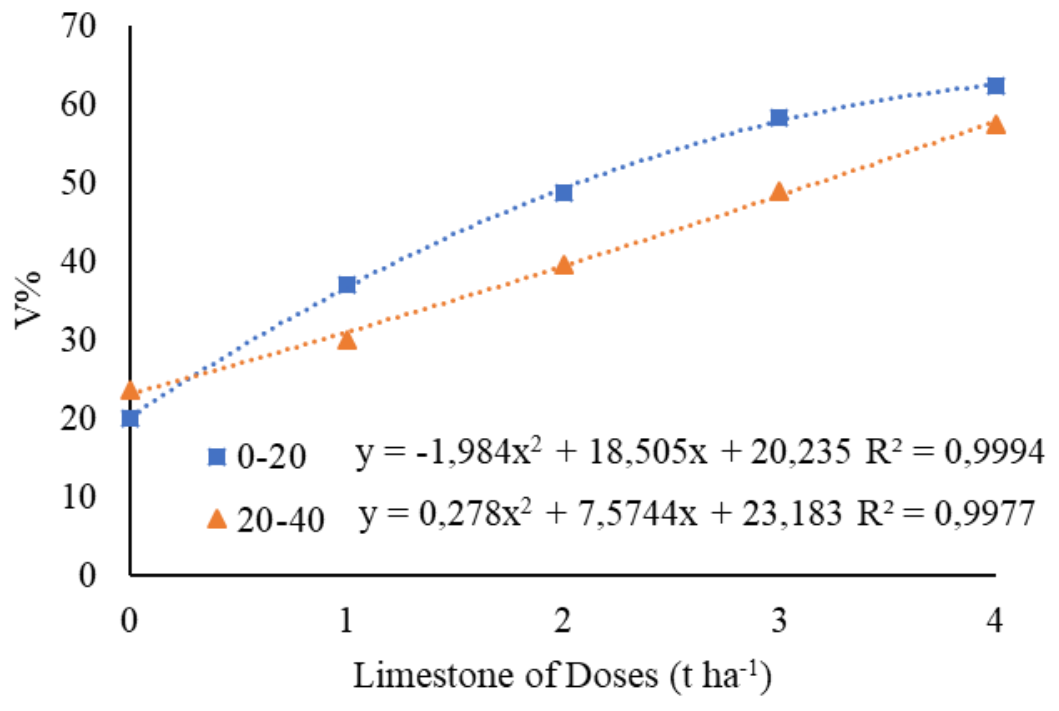

Figure 15. V\% content as a function of limestone application. 


\section{Macrothink}

Corn yield in the third crop cycle was influenced by lime and gypsum doses. The application of limestone promoted an increase in grain yield due to the correction promoted by this soil conditioner (Figure 16), by increasing the $\mathrm{pH}$ and reducing the exchangeable $\mathrm{Al}^{3+}$, and incrementing base content $\left(\mathrm{Ca}^{2+}\right.$ equal to $2.78 \mathrm{cmol}_{\mathrm{c}} \mathrm{dm}^{-3}$ and $\mathrm{Ca}+\mathrm{Mg}$ equal to $4.12 \mathrm{cmol}_{\mathrm{c}}$ $\mathrm{dm}^{-3}$ ) in the soil. As in the previous year, the transport of bases from the gypsum application promoted base movement over the profile; however, this increase in the bases below the $20-\mathrm{cm}$ depth did not reflect an increase in grain production and it may be inferred that the increase promoted by limestone directly contributed to the increase in crop production. The presence of gypsum and limestone in the production of corn had a greater response in the no-tillage system. This may be related to the less toxic effect of aluminum over the 36 months after application, contributing to the formation of soluble organic compounds present in cultural remains. With a corrective action by the two conditioners, the levels of calcium and magnesium were available in the soil profile for their absorption.

The maximum levels found for $\mathrm{Ca}^{2+}$ and $\mathrm{Ca}+\mathrm{Mg}$ as a function of the application of limestone $\left(3.73 \mathrm{tha}^{-1}\right)$ and gypsum $\left(0.75 \mathrm{t} \mathrm{ha}^{-1}\right)$ were reflected in corn production, with average yield of $5572 \mathrm{~kg} \mathrm{ha}^{-1}$ (Figure 16). Zandoná et al. (2015) in soybean and corn after the application of gypsum with and without lime in a no-tillage system, which is related to the increase in productivity due to the increase in $\mathrm{Ca}^{2+}, \mathrm{Mg}^{2+}$, phosphorus and reduction in aluminum saturation

\section{Yield $=4463,2138+648,4095^{*} x-107,0254^{*} y+298,4655^{*} x^{*} x-52,9646^{*} x^{*} y+71,9982^{*} y^{\star} y$}

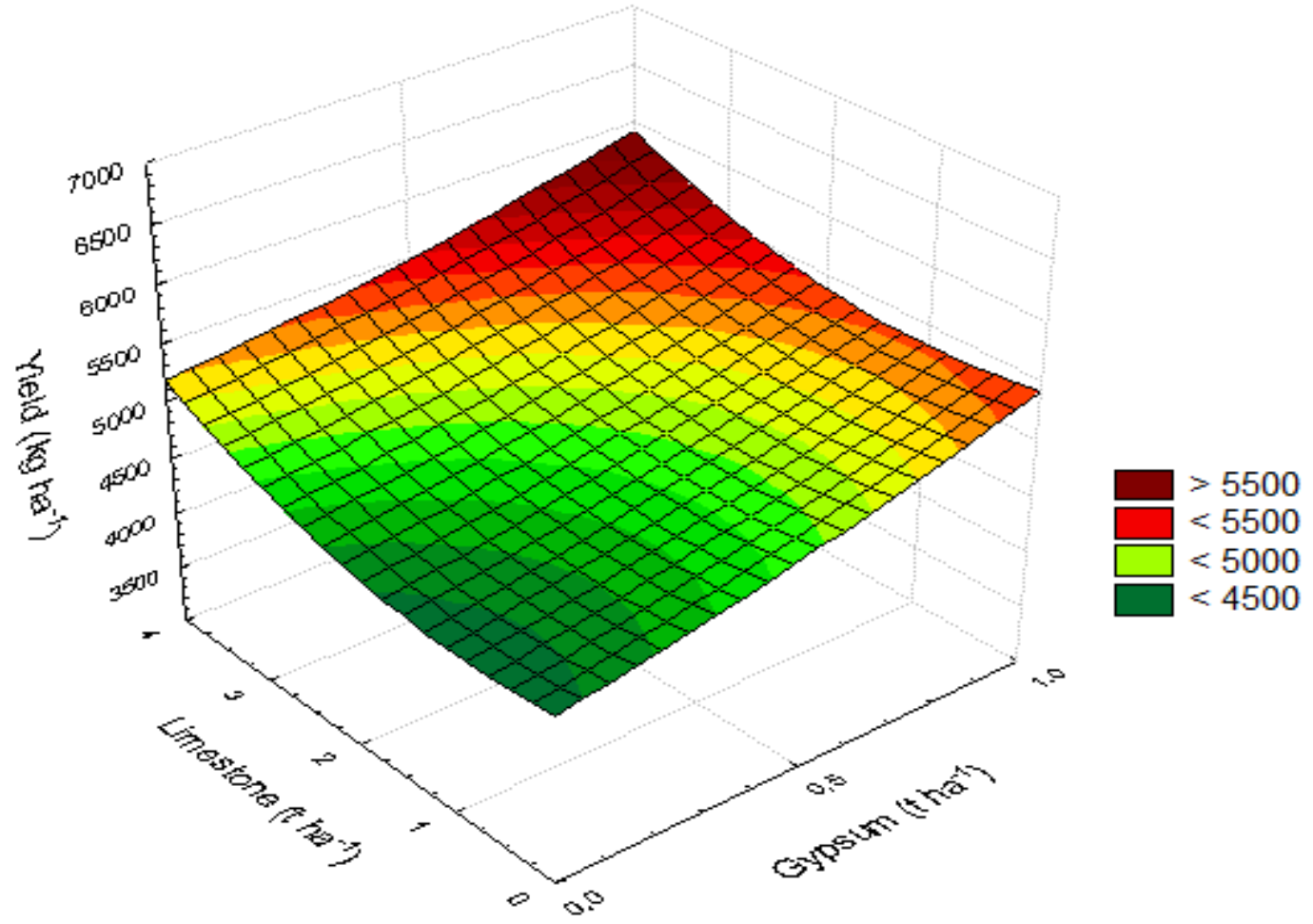

Figure 16. Corn grain yield due to limestone and gypsum application in the third agricultural cycle 


\section{Conclusion}

This work showed that the application of limestone and gypsum in soil cultivated under no-tillage system promotes improvements in soil chemical attributes related to acidity $(\mathrm{pH}$, $\mathrm{Ca}^{2+}, \mathrm{Ca}+\mathrm{Mg}$ and $\left.\mathrm{Al}^{3+}\right)$. Limestone acts only in the topsoil, neutralizing soil acidity (increment in $\mathrm{pH}$ and reduction in exchangeable $\mathrm{Al}$ ) at the implantation of this system and its residual effect is found until the third year of cultivation. The use of agricultural gypsum in the production system promotes an increase in the in-depth exchangeable $\mathrm{Ca}^{2+}$ and $\mathrm{Mg}^{2+}$ contents, contributing to the increase in V\% indices in the subsurface layer. In the implementation of the no-tillage system, only the application of limestone promotes an increase in corn yield, but in the second and third years, there is a response of the crop, due to the combined action with the gypsum.

\section{References}

Albuquerque, J. A., Bayer, C., Ernani, P. R., Mafra, A. L., \& Fontana, E. C. (2003). Aplicação de calcário e fósforo e estabilidade da estrutura de um solo ácido. Revista brasileira de ciencia do solo. Campinas. 27(5) (set./out. 2003), 799-806. https://doi.org/10.1590/S0100-06832003000500004

Basso, C. J., Somavilla, L., da Silva, R. F., \& Santi, A. L. (2015). Intervenção mecânica e gesso agrícola para mitigar o gradiente vertical de cátions sob sistema de plantio direto. Pesquisa Agropecuária Tropical (Agricultural Research in the Tropics), 456-463. https://doi.org/10.1590/1983-40632015v4537764

Bortolanza, D. R., \& Klein, V. A. (2016). Soil Chemical and Physical Properties on an Inceptisol after Liming (Surface and Incorporated) Associated with Gypsum Application. Revista Brasileira de Ciência do Solo, 40. https://doi.org/10.1590/18069657rbcs20150377

Briedis, C., de Moraes Sá, J. C., Caires, E. F., de Fátima Navarro, J., Inagaki, T. M., \& de Oliveira Ferreira, A. (2012). Carbono do solo e atributos de fertilidade em resposta à calagem superficial em plantio direto. Pesquisa agropecuária brasileira,47(7), 1009-1016. https://doi.org/10.1590/S0100-204X2012000700018

Caires, E. F., Alleoni, L. R., Cambri, M. A., \& Barth, G. (2005). Surface application of lime for crop grain production under a no-till system. Agronomy Journal, 97(3), 791-798. https://doi.org/10.2134/agronj2004.0207

Caires, E. F., Blum, J., Barth, G., Garbuio, F. J., \& Kusman, M. T. (2003). Alterações químicas do solo e resposta da soja ao calcário e gesso aplicados na implantação do sistema plantio direto. Revista Brasileira de Ciência do Solo, 27(2), 275-286. https://doi.org/10.1590/S0100-06832003000200008

Caires, E. F., Joris, H. A. W., \& Churka, S. (2011). Long-term effects of lime and gypsum additions on no-till corn and soybean yield and soil chemical properties in southern Brazil. Soil Use and Management, 27(1), 45-53. https://doi.org/10.1111/j.1475-2743.2010.00310.x

Carvalho, J. L. N., Avanzi, J. C., Silva, M. L. N., Mello, C. R., \& Cerri, C. E. P. (2010). 
Potencial de sequestro de carbono em diferentes biomas do brasil. Revista Brasileira de Ciência do Solo, 34, 277-289. https://doi.org/10.1590/S0100-06832010000200001

Cravo, M. S., Jot Smyth, T., \& Brasil, E. C. (2012). Calagem em Latossolo amarelo distrófico da Amazônia e sua influência em atributos químicos do solo e na produtividade de culturas anuais. Revista Brasileira de Ciência do Solo, 36(3). https://doi.org/10.1590/S0100-06832012000300020

Crusciol, C. A., Artigiani, A. C., Arf, O., Carmeis Filho, A. C., Soratto, R. P., Nascente, A. S., \& Alvarez, R. C. (2016). Soil fertility, plant nutrition, and grain yield of upland rice affected by surface application of lime, silicate, and phosphogypsum in a tropical no-till system. Catena, 137, 87-99. https://doi.org/10.1016/j.catena.2015.09.009

da Costa, C. H. M., \& Crusciol, C. A. C. (2016). Long-term effects of lime and phosphogypsum application on tropical no-till soybean-oat-sorghum rotation and soil chemical properties. European journal of agronomy, 74, 119-132. https://doi.org/10.1016/j.eja.2015.12.001

da Silva, M. A. G., Muniz, A. S., da Mata, J. D. D. V., Carissimi, C., \& Cegana, A. C. (2003). Amostragem e variabilidade nos atributos de fertilidade em um latossolo sob plantio direto em São Miguel do Iguaçu, Estado do Paraná. Acta Scientiarum. Agronomy, 25(1), 243-248. https://doi.org/10.4025/actasciagron.v25i1.2679

Ernani, P. R., Ribeiro, M. S., \& Bayer, C. (2001). Modificações químicas em solos ácidos ocasionadas pelo método de aplicação de corretivos da acidez e de gesso agrícola. Scientia Agricola, 58(4), 825-831. https://doi.org/10.1590/S0103-90162001000400026

FAO - Food and Agriculture Organization of the United Nations. Disponível em:< http://www.fao.org/faostat/en/\#data/QC>. Acesso: janeiro de 2020.

Fink, J. R., Inda, A. V., Bayer, C., Torrent, J., \& Barrón, V. (2014). Mineralogy and phosphorus adsorption in soils of south and central-west Brazil under conventional and no-tillage systems. Acta Scientiarum. Agronomy, 36(3), 379-387. https://doi.org/10.4025/actasciagron.v36i3.17937

Gama, J. R. N. F., Rodrigues, T. E., \& Cardoso Junior, E. Q. Levantamento dos solos e uso atual do campo experimental de Terra Alta, Pará. Belém, Embrapa Amazônia Oriental, 2000. (Documentos, 45).

Hansel, F. D., Ruiz Diaz, D. A., Amado, T. J., \& Rosso, L. H. (2017). Deep banding increases phosphorus removal by soybean grown under no-tillage production systems. Agronomy Journal, 109(3), 1091-1098. https://doi.org/10.2134/agronj2016.09.0533

Joris, H. A. W., Caires, E. F., Bini, A. R., Scharr, D. A., \& Haliski, A. (2013). Effects of soil acidity and water stress on corn and soybean performance under a no-till system. Plant and soil, 365(1-2), 409-424. https://doi.org/10.1007/s11104-012-1413-2

Miyazawa, M., Pavan, M. A., \& Franchini, J. C. (2002). Evaluation of plant residues on the mobility of surface applied lime. Brazilian Archives of Biology and Technology, 45(3), 
251-256. https://doi.org/10.1590/S1516-89132002000300001

Nascimento, R., Souza, J. A. D., Moreira, A., \& Moraes, L. A. C. (2017). Phosphogypsum and vinasse application: soil chemical properties and alfalfa productivity and nutritional $\begin{array}{llll}\text { characteristics. } & \text { Revista } & \text { Caatinga, } & \text { 213-219. }\end{array}$ https://doi.org/10.1590/1983-21252017v30n123rc

Nora, D. D., Amado, T. J. C., Nicoloso, R. D. S., Mazuco, A. C. B., \& Piccin, M. (2017). Mitigation of the gradient of chemical properties in the rooting zone of dystrophic Oxisols by gypsum and lime inputs under a no-till system. Revista Brasileira de Ciência do Solo, 41. https://doi.org/10.1590/18069657rbcs20150541

Quaggio, J. A., van Raij, B., Gallo, P. B., \& Mascarenhas, H. A. A. (1993). Respostas da soja à aplicação de calcário e gesso e lixiviação de íons no perfil do solo. Pesquisa Agropecuária Brasileira, 28(3), 375-383.

Ramos, B. Z., Toledo, J. P. V. F., de Lima, J. M., Serafim, M. E., Bastos, A. R. R., Guimarães, P. T. G., \& Coscione, A. R. (2013). Doses de gesso em cafeeiro: influência nos teores de cálcio, magnésio, potássio e $\mathrm{pH}$ na solução de um Latossolo Vermelho distrófico. Revista $\begin{array}{lllll}\text { Brasileira de Ciência do } & \text { Solo, } & 37(4), & 1018-1026 .\end{array}$ https://doi.org/10.1590/S0100-06832013000400019

Rheinheimer, D. S., Tiecher, T., Gonzatto, R., Zafar, M., \& Brunetto, G. (2018). Residual effect of surface-applied lime on soil acidity properties in a long-term experiment under no-till in a Southern Brazilian sandy Ultisol. Geoderma, 313, 7-16. https://doi.org/10.1016/j.geoderma.2017.10.024

Rodrighero, M. B., Barth, G., \& Caires, E. F. (2015). Aplicação superficial de calcário com diferentes teores de magnésio e granulometrias em sistema plantio direto. Revista Brasileira de Ciência do Solo, 39(6), 1723-1736. https://doi.org/10.1590/01000683rbcs20150036

Rossato, O. B., Foltran, R., Crusciol, C. A. C., Martello, J. M., Rossetto, R., \& McCray, J. M. (2017). Soil fertility, ratoon sugarcane yield, and post-harvest residues as affected by surface application of lime and gypsum in southeastern Brazil. Bioscience Journal, 33(2). https://doi.org/10.14393/BJ-v33n2-32755

Shamshuddin, J., \& Fauziah, C. I. (2010). Alleviating acid soil infertility constraints using basalt, ground magnesium limestone and gypsum in a tropical environment. Malays. J. Soil Sci, 14, 1-13.

Soratto, R. P., \& Crusciol, C. A. (2008). Dolomite and phosphogypsum surface application effects on annual crops nutrition and yield. Agronomy Journal, 100(2), 261-270. https://doi.org/10.2134/agronj2007.0120

Soratto, R. P., \& Crusciol, C. A. C. (2008). Atributos químicos do solo decorrentes da aplicação em superfície de calcário e gesso em sistema plantio direto recém-implantado. Revista Brasileira de Ciência do Solo, 675-688. https://doi.org/10.1590/S0100-06832008000200022 


\section{Mll Macrothink}

Souza, P. J. D. O. P., Farias, V. D. D. S., Lima, M. J. A. D., Ramos, T. F., \& Sousa, A. (2017). Cowpea leaf area, biomass production and productivity under different water regimes in $\begin{array}{lllll}\text { Castanhal, } & \text { Pará, } & \text { Brazil. } & \text { Revista } & \text { Catinga, }\end{array}$ https://doi.org/10.1590/1983-21252017v30n323rc

Tiritan, C. S., Büll, L. T., Crusciol, C. A., Carmeis Filho, A. C., Fernandes, D. M., \& Nascente, A. S. (2016). Tillage system and lime application in a tropical region: soil chemical fertility and corn yield in succession to degraded pastures. Soil and Tillage Research, 155, 437-447. https://doi.org/10.1016/j.still.2015.06.012

Valadão, F. C. A., Dos Santos Weber, O. L., Valadao Junior, D. D., Scapinelli, A., Deina, F. R., \& Bianchini, A. (2015). Adubação fosfatada e compactação do solo: sistema radicular da soja e do milho e atributos físicos do solo. Revista Brasileira de Ciência do Solo, 39(1). https://doi.org/10.1590/01000683rbcs20150144

Vicensi, M., Müller, M. M. L., Kawakami, J., Nascimento, R. D., Michalovicz, L., \& Lopes, C. (2016). Do rates and splitting of phosphogypsum applications influence the soil and annual crops in a no-tillage system? Revista Brasileira de Ciência do Solo, 40. https://doi.org/10.1590/18069657rbcs20150155

Zambrosi, F. C. B., Alleoni, L. R. F., \& Caires, E. F. (2007). Aplicação de gesso agrícola e especiação iônica da solução de um Latossolo sob sistema plantio direto. Ciência Rural, 37(1), 110-117. https://doi.org/10.1590/S0103-84782007000100018

Zandoná, R. R., Beutler, A. N., Burg, G. M., Farias Barreto, C., \& Schmidt, M. R. (2015). Gesso e calcário aumentam a produtividade e amenizam o efeito do déficit hídrico em milho e soja1. Pesquisa Agropecuária Tropical, 45(2). https://doi.org/10.1590/1983-40632015v4530301

\section{Copyright Disclaimer}

Copyright for this article is retained by the author(s), with first publication rights granted to the journal.

This is an open-access article distributed under the terms and conditions of the Creative Commons Attribution license (http://creativecommons.org/licenses/by/4.0/). 